United States of America, Plaintiff,

\title{
IN THE UNITED STATES DISTRICT COURT
} FOR THE DISTRICT OF ARIZONA

vs.

State of Arizona; and Janice K. Brewer,

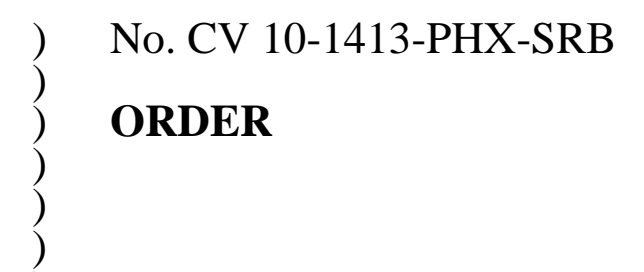
Governor of the State of Arizona, in her) Official Capacity, Defendants. 
to check a person's immigration status under certain circumstances (Section 2) and authorizes officers to make a warrantless arrest of a person where there is probable cause to believe that the person committed a public offense that makes the person removable from the United States (Section 6). S.B. 1070 also creates or amends crimes for the failure of an alien

[i]f a provision of this act or its application to any person or circumstance is held invalid, the invalidity does not affect other provisions or applications of the act that can be given effect without the invalid provision or application, and to this end the provisions of this act are severable.

S.B. $1070 \S 12(A)$. Therefore, the Court cannot and will not enjoin S.B. 1070 in its entirety, as certain parties to lawsuits challenging the enactment have requested. The Court is obligated to consider S.B. 1070 on a section by section and provision by provision basis.

Other than seeking a preliminary injunction as to "S.B. 1070,” the United States has not made any argument to preliminarily enjoin and the Court therefore does not enjoin the following provisions of S.B. 1070:

Section 1 of S.B. 1070 no A.R.S. citation:

providing the intent of the legislation 
Portions of Section 2 of S.B. 1070

A.R.S. § 11-1051(A): prohibiting Arizona officials, agencies, and political subdivisions from limiting enforcement of federal immigration laws

A.R.S. § 11-1051(C)-(F): requiring that state officials work with federal officials with regard to unlawfully present aliens

A.R.S. § 11-1051(G)-(L): allowing legal residents to sue any state official, agency, or political subdivision for adopting a policy of restricting enforcement of federal immigration laws to less than the full extent permitted by federal law

Section 4 of S.B. $1070^{2}$

A.R.S. § 13-2319:

amending the crime of human smuggling

Portion of Section 5 of S.B. 1070

A.R.S. § 13-2928(A)-(B): creating a crime for stopping a motor vehicle to pick up day laborers and for day laborers to get in a motor vehicle if it impedes the normal movement of traffic

Section 7 of S.B. 1070

A.R.S. § 23-212:

amending the crime of knowing employment of unauthorized aliens

Section 8 of S.B. 1070

A.R.S. § 23-212.01:

amending the crime of intentional employment of unauthorized aliens

Section 9 of S.B. 1070

A.R.S. § 23-214:

amending the requirements for checking employment eligibility

Section 11 of S.B. 1070

A.R.S. § 41-1724:

creating the gang and immigration intelligence team enforcement mission fund

Sections 12 \& 13 of S.B. 1070

no A.R.S. citation: administering S.B. 1070

Applying the proper legal standards based upon well-established precedent, the Court finds that the United States is not likely to succeed on the merits in showing that the following provisions of S.B. 1070 are preempted by federal law, and the Court therefore does not enjoin the enforcement of the following provisions of S.B. 1070:

${ }^{2}$ Although the United States' Complaint challenges Section 4 of S.B. 1070, counsel for the United States stated at oral argument that the federal government is not seeking to enjoin 
Section 10 of S.B. 1070

A.R.S. § 28-3511:

Portion of Section 5 of S.B. 1070

A.R.S. § 13-2929:

creating a separate crime for a person in violation of a criminal offense to transport or harbor an unlawfully present alien or encourage or induce an unlawfully present alien to come to or live in Arizona

amending the provisions for the removal or impoundment of a vehicle to permit impoundment of vehicles used in the transporting or harboring of unlawfully present aliens

Applying the proper legal standards based upon well-established precedent, the Court finds that the United States is likely to succeed on the merits in showing that the following Sections of S.B. 1070 are preempted by federal law:

Portion of Section 2 of S.B. 1070

A.R.S. § 11-1051(B): requiring that an officer make a reasonable attempt to determine the immigration status of a person stopped, detained or arrested if there is a reasonable suspicion that the person is unlawfully present in the United States, and requiring verification of the immigration status of any person arrested prior to releasing that person

Section 3 of S.B. 1070

A.R.S. § 13-1509:

creating a crime for the failure to apply for or carry alien registration papers

Portion of Section 5 of S.B. 1070

A.R.S. § 13-2928(C): creating a crime for an unauthorized alien to solicit, apply for, or perform work

Section 6 of S.B. 1070

A.R.S. § 13-3883(A)(5):

authorizing the warrantless arrest of a person where there is probable cause to believe the person has committed a public offense that makes the person removable from the United States

The Court also finds that the United States is likely to suffer irreparable harm if the Court does not preliminarily enjoin enforcement of these Sections of S.B. 1070 and that the balance of equities tips in the United States' favor considering the public interest. The Court therefore issues a preliminary injunction enjoining the enforcement of the portion of Section 2 creating A.R.S. § 11-1051(B), Section 3 creating A.R.S. § 13-1509, the portion of Section 5 creating A.R.S. § 13-2928(C), and Section 6 creating A.R.S. § 13-3883(A)(5). 
1 II. BACKGROUND

\section{A. Overview of Federal Immigration Law}

Congress has created and refined a complex and detailed statutory framework regulating immigration. The federal immigration scheme is largely enacted through the Immigration and Nationality Act (“INA”), 8 U.S.C. § 1101, et seq., which empowers various federal agencies (including the Department of Justice (“DOJ”), Department of Homeland Security ("DHS”), and Department of State ("DOS”)) to administer and enforce the immigration laws. See, e.g., id. §§ 1103-1104. Among its many provisions, the INA sets forth the conditions under which a foreign national may be admitted to and remain in the United States. Id. §§ 1181-1182, 1184. The INA also contains an alien registration system intended to monitor the entry and movement of aliens in the United States. Id. §§ 1201(b), 1301-1306. Various actions may subject an alien to being placed in removal proceedings, such as entering the United States without inspection, presenting fraudulent documents at a port of entry, violating the conditions of admission, or engaging in certain other proscribed conduct. Id. $\S \S$ $1225,1227,1228,1229,1229$ c, 1231. Violations of immigration laws may also subject an alien to civil and criminal sanctions. E.g., id. $\S \S 1325,1306,1324 c$. Unlawful presence in the United States is not a federal crime, although it may make the alien removable. See id. §§ 1182(a)(6)(A)(i), 1227(a)(1)(B)-(C). ${ }^{3}$

Federalaliensmugglinglaws mak into the country, as well as to harbor such a person or to facilitate unlawful immigration. Id. § 1324. Congress also created sanctions to be implemented against employers who knowingly employ aliens who are not authorized to work when it passed the Immigration Reform and Control Act ("IRCA") in 1986. Id. § 1324a(a)(1)-(2). Federal law contains no criminal sanction for working without authorization, although document fraud is a civil violation under IRCA. Id. § 1324c. In 1996, Congress passed the Illegal Immigration Reform and Immigrant

${ }^{3}$ Unlawful presence is an element of the federal crime of reentry after deportation, 8 U.S.C. $\S 1326$, and unlawful entry into the United States is also a federal crime, 8 U.S.C. § 1325. 
1 Responsibility Act ("IIRIRA"), which, among other things, created various employment

2 eligibility verification programs. See Chicanos Por La Causa, Inc. v. Napolitano (Chicanos 3 Por La Causa II), 558 F.3d 856, 861 (9th Cir. 2009).

Federal immigration law also envisions certain areas of cooperation in immigration enforcement among the federal government and state and local governments. See 8 U.S.C. § 1357(g)(1)-(9) (permitting DHS to enter into agreements whereby appropriately trained and supervised state and local officials can perform certain immigration responsibilities); id. $\S$ 1373 (establishing parameters for information-sharing between state and local officials and federal immigration officials); id. § 1252c (authorizing state and local law enforcement officials to arrest aliens unlawfully present in the United States who have previously been convicted of a felony and deported). DHS has also established the Law Enforcement Support Center (“LESC”), which is administered by Immigration and Customs Enforcement (“ICE”) and serves as a national enforcement information center, answering queries from state and local officials regarding immigration status. (Pl.’s Mot., Ex. 3, Decl. of David Palmatier, Unit Chief for LESC (“Palmatier Decl.”) ๆๆ 3-6.)

\section{B. Overview of S.B. 1070}

\section{Section 1}

Section 1 of S.B. 1070 states that "the intent of [S.B. 1070] is to make attrition through enforcement the public policy of all state and local government agencies in Arizona" and that “[ $t$ ]he provisions of this act are intended to work together to discourage and deter the unlawful entry and presence of aliens and economic activity by persons unlawfully present in the United States." Section 1 also states that "there is a compelling interest in the cooperative enforcement of federal immigration laws throughout all of Arizona."

\section{Section 2}

Section 2 of S.B. 1070 adds A.R.S. § 11-1051. Section 2 contains twelve separate subsections. Subsection 2(A) prohibits Arizona officials, agencies and political subdivisions from limiting or restricting the enforcement of federal immigration laws. A.R.S. § 111051(A). Subsection 2(B) requires officers to make a reasonable attempt, when practicable, 
1 to determine an individual's immigration status during any lawful stop, detention, or arrest

2 where reasonable suspicion exists that the person is unlawfully present in the United States.

3 Id. § 11-1051(B). Subsection 2(B) also requires that all persons who are arrested have their

4 immigration status verified prior to release. Id. Subsections 2(B) and 2(E) provide the process

5 for verifying immigration status and list documents that create a presumption of lawful

6 presence. Id. § 11-1051(B), (E). Mandatory stops for the purpose of immigration status

7 verification are not required or authorized by Subsection 2(B). Subsection 2(C) requires

8 notification of ICE or Customs and Border Protection whenever an unlawfully present alien

9 is discharged or assessed a monetary obligation. Id. § 11-1051(C). Subsections 2(D) and (F)

10 permit law enforcement to securely transport unlawfully present aliens and send, receive, and

11 exchange information related to immigration status. Id. § 11-1051(D), (F).

12 In addition, Subsection 2(H) permits legal residents of Arizona to bring actions in state

13 court "to challenge any official or agency of [Arizona] that adopts or implements a policy or

14 practice that limits or restricts the enforcement of federal immigration laws to less than the

15 full extent permitted by federal law.” Id. § 11-1051(H). Subsections 2(I) and (J) address the

16 civil penalties arising from such civil suits, and Subsection 2(K) provides that law

17 enforcement officers are indemnified against reasonable costs and expenses incurred by the

18 officer in connection with any suit initiated under this Section unless the officer is found to

19 have acted in bad faith. Id. § 11-1051(I)-(K).

20 3. Section 3

21 Section 3 of S.B. 1070 adds A.R.S. § 13-1509, which provides that "a person is guilty

22 of willful failure to complete or carry an alien registration document if the person is in

23 violation of [8 U.S.C. §§] 1304(e) or 1306(a)," federal statutes that require aliens to carry

24 documentation of registration and penalize the willful failure to register. A.R.S. § 13-1509(A).

25 Violation of Section 3 is a class 1 misdemeanor and results in a maximum fine of \$100 and

26 a maximum of 20 days in jail for a first violation and up to 30 days in jail for any subsequent

27 violation. Id. § 13-1509(H). Section 3 limits a violator’s eligibility for a suspended sentence,

28 probation, pardon, and commutation of a sentence and requires violators to pay jail costs. Id. 
1 § 13-1509(D), (E). In the enforcement of Section 3, immigration status may be determined

2 by a law enforcement officer authorized by the federal government or pursuant to 8 U.S.C.

3 § 1373(c). Id. § 13-1509(B). Pursuant to Subsection 3(C), law enforcement officers are not

4 permitted to consider race, color, or national origin in the enforcement of Section 3. Id. § 131509(C). Finally, Section 3 does not apply to "a person who maintains authorization from the federal government to remain in the United States.” Id. § 13-1509(F).

\section{Section 4}

In Section 4 of S.B. 1070, the Arizona Legislature revised A.R.S. § 13-2319 by adding a provision that permits officers enforcing Arizona's human smuggling statute to stop any person who is operating a motor vehicle if the officer has reasonable suspicion to believe that the person is in violation of any civil traffic law. Id. § 13-2319(E). Section 4 does not make any other changes or additions to Arizona’s human smuggling statute, A.R.S. § 13-2319.

\section{Section 5}

Section 5 of S.B. 1070 adds two provisions to the Arizona Criminal Code, A.R.S. $\S \S$ 13-2928 and 13-2929. A.R.S. § 13-2928(A) provides that it is unlawful for an occupant of a motor vehicle that is stopped on a street, roadway, or highway and is impeding traffic to attempt to hire a person for work at another location. Id. § 13-2928(A). Similarly, A.R.S. § 13-2928(B) provides that it is unlawful for a person to enter a motor vehicle in order to be hired if the vehicle is stopped on a street, roadway, or highway and is impeding traffic. Id. § 13-2928(B). Finally, A.R.S. § 13-2928(C) provides that it is unlawful "for a person who is unlawfully present in the United States and who is an unauthorized alien to knowingly apply for work, solicit work in a public place or perform work as an employee or independent contractor in this state.” Id. $\S 13-2928(C)$. Violation of A.R.S. $\S 13-2928$ is a class 1 misdemeanor. Id. § 13-2928(F).

Section 5 of S.B. 1070 also creates A.R.S. § 13-2929, which provides that it is unlawful for a person who is in violation of a criminal offense to: (1) transport or move or attempt to transport or move an alien in Arizona in furtherance of the alien's unlawful presence in the United States; (2) conceal, harbor, or shield or attempt to conceal, harbor, or 
shield an alien from detection in Arizona; and (3) encourage or induce an alien to come to or live in Arizona. Id. § 13-2929(A)(1)-(3). In order to violate A.R.S. § 13-2929(A), a person must also know or recklessly disregard the fact that the alien is unlawfully present in the United States. Id. Violation of A.R.S. § 13-2929 is a class 1 misdemeanor. Id. § 13-2929(F).

\section{Section 6}

Section 6 of S.B. 1070 amends A.R.S. § 13-3883 to permit an officer to arrest a person without a warrant if the officer has probable cause to believe that "the person to be arrested has committed any public offense that makes the person removable from the United States.” Id. § 13-3883(A)(5).

\section{Sections 7-13}

Sections 7, 8, and 9 amend Arizona's law imposing sanctions on employers who hire unlawfully present aliens. See A.R.S. §§ 23-212, 23-212.01, 23-214. Section 10 amends A.R.S. § 28-3511 to allow for the immobilization or impoundment of vehicles used in the transporting and concealing of unlawfully present aliens where the driver of the vehicle knew or recklessly disregarded the fact that the alien was unlawfully present. Section 11 creates the "gang and immigration intelligence team enforcement mission fund" for civil penalties paid pursuant to Subsection 2(I). Finally, Section 12 provides for the severance of any unconstitutional provisions, and Section 13 provides a short title for the enactment.

\section{Procedural Posture}

The United States filed its Complaint challenging the constitutionality of S.B. 1070 on July 6, 2010, naming as Defendants the State of Arizona and Governor Brewer in her official capacity (collectively, “Arizona”). On the same day, it also filed a Motion requesting that the Court preliminarily enjoin Arizona from enforcing S.B. 1070 until the Court can make a final determination as to its constitutionality. (Doc. 6, Pl.’s Lodged Proposed Mot. for Prelim. Inj.) The United States argues principally that the power to regulate immigration is vested exclusively with the federal government, and the provisions of S.B. 1070 are therefore preempted by federal law. The Court held a Hearing on Plaintiff's Motion on July 22, 2010 
1 (“the Hearing”). S.B. 1070 has an effective date of July 29, 2010. The Court now considers

2 the United States’ Motion for Preliminary Injunction.

3 III. LEGAL STANDARDS AND ANALYSIS

\section{A. General Legal Standards}

“A plaintiff seeking a preliminary injunction must establish that he is likely to succeed on the merits, that he is likely to suffer irreparable harm in the absence of preliminary relief, that the balance of equities tips in his favor, and that an injunction is in the public interest." Winter v. Natural Res. Def. Council, Inc., 129 S. Ct. 365, 374 (2008) (citations omitted).

The United States primarily asserts that the statutory provisions contained in S.B. 1070 are preempted by federal law. The Supremacy Clause of the United States Constitution makes federal law "the supreme law of the land." U.S. Const. art. VI, cl. 2. The Supreme Court has consistently ruled that the federal government has broad and exclusive authority to regulate immigration, supported by both enumerated and implied constitutional powers. ${ }^{4}$ While holding that the "[p]ower to regulate immigration is unquestionably exclusively a federal power," the Supreme Court concluded that not every state enactment "which in any way deals with aliens is a regulation of immigration and thus per se preempted by this constitutional power, whether latent or exercised.” De Canas v. Bica, 424 U.S. 351, 354-355 (1976).

Federal preemption can be either express or implied. Chicanos Por La Causa v. Napolitano (Chicanos Por La Causa I), 544 F.3d 976, 982 (9th Cir. 2008), cert. granted, 78 U.S.L.W. 3065, 78 U.S.L.W. 3754, 78 U.S.L.W. 3762 (U.S. June 28, 2010) (No. 09-115). There are two types of implied preemption: field preemption and conflict preemption. Id. Field preemption occurs "where 'the depth and breadth of a congressional scheme . . . occupies the legislative field."” Id. (quoting Lorillard Tobacco Co. v. Reilly, 533 U.S. 525,

${ }^{4}$ A variety of enumerated powers implicate the federal government's long-recognized immigration power, including the Commerce Clause, the Naturalization Clause, and the Migration and Importation Clause. See U.S. Const. art. I, § 8, cl. 3-4; art. I, § 9, cl. 1; see also Fong Yue Ting v. United States, 149 U.S. 698, 706 (1893); Chae Chan Ping v. United States, 130 U.S. 581, 603-04 (1889). 
1

2

541 (2001)). Conflict preemption describes a situation in which "compliance with both federal and state regulations is a physical impossibility or where state law stands as an obstacle to the accomplishment and execution of the full purposes and objectives of Congress." Id. (internal quotations and citations omitted). An actual, as opposed to hypothetical or potential, conflict must exist for conflict preemption to apply. Id.

\section{B. Likelihood of Success on the Merits}

The United States must first demonstrate a likelihood of success on the merits. Winter, 129 S. Ct. at 374. The United States challenges S.B. 1070 on its face, before it takes effect on July 29, 2010. (Pl.’s Mot. at 7.) “A facial challenge to a legislative Act is, of course, the most difficult challenge to mount successfully, since the challenger must establish that no set of circumstances exists under which the Act would be valid." United States v. Salerno, 481 U.S. 739, 745 (1987). The Supreme Court later observed, in considering a facial challenge, “[S]ome Members of the Court have criticized the Salerno formulation, [but] all agree that a facial challenge must fail where a statute has a 'plainly legitimate sweep." Wash. State Grange v. Wash. State Republican Party, 552 U.S. 442, 449 (2008) (quoting Washington v. Glucksberg, 521 U.S. 702, 739-40 \& n.7 (1997) (Stevens, J., concurring in judgments)). In deciding a facial challenge, courts "must be careful not to go beyond the statute's facial requirements and speculate about 'hypothetical' or 'imaginary' cases.” Id. at 449-50 (quoting United States v. Raines, 362 U.S. 17, 22 (1960)).

\section{Preemption of Overall Statutory Scheme}

As discussed above, S.B. 1070 contains several provisions adding to and amending Arizona law. While the United States has requested that the Court enjoin S.B. 1070 in its entirety, it specifically challenges only select provisions of S.B. 1070. (See Pl.'s Mot. at 12 n.8 (noting that "the instant motion does not seek to enjoin" Sections 7-9 of S.B. 1070 and that Sections 11-13 “are administrative provisions which are not the subject of this dispute").) The United States also argues that the overall statutory scheme of S.B. 1070 is preempted because it attempts to set immigration policy at the state level and interferes and conflicts with federal 
1 immigration law, foreign relations, and foreign policy. (Id. at 12-25.) Section 1 of S.B. 1070

2 declares a unified, state-wide public policy, providing:

The legislature declares that the intent of this act is to make attrition through enforcement the public policy of all state and local government agencies in Arizona. The provisions of this act are intended to work together to discourage and deter the unlawful entry and presence of aliens and economic activity by

\section{S.B. 1070 § 1. The United States urges the Court to enjoin S.B. 1070 as an integrated statutory} enactment with interlocking provisions. (Pl.’s Mot. at 12-25.) The United States asserts that Section 1 animates and "infuses" the operative sections of the law. (Hr'g Tr. 13:4-14:5.)

"[W]hen the constitutionality of a state statute is challenged, principles of state law guide the severability analysis and [courts] should strike down only those provisions which are inseparable from the invalid provisions." Costco Wholesale Corp. v. Maleng, 522 F.3d 874, 886 (9th Cir. 2008) (citing Tucson Woman's Clinic v. Eden, 379 F.3d 531, 556-57 (9th Cir. 2004)). "A court should not declare an entire statute unconstitutional if the constitutional portions can be severed from those which are unconstitutional.” State v. Ramsey, 831 P.2d 408, 413 (Ariz. Ct. App. 1992) (citing State v. Prentiss, 786 P.2d 932, 937 (Ariz. 1989)). Under Arizona law,

it is well settled ... that where the valid parts of a statute are effective and enforceable standing alone and independent of those portions declared unconstitutional, the court will not disturb the valid law if the valid and invalid portions are not so intimately connected as to raise the presumption the legislature would not have enacted one without the other, and the invalid portion was not the inducement of the act.

Selective Life Ins. Co. v. Equitable Life Assurance Soc'y of the U.S., 422 P.2d 710, 715 (Ariz. 1967) (citing McCune v. City of Phx., 317 P.2d 537, 542 (Ariz. 1957)). In determining whether potentially unconstitutional provisions of S.B. 1070 may be severed from the remainder of the enactment, the primary concern is legislative intent. See id. at 715-16 (citing City of Mesa v. Killingsworth, 394 P.2d 410, 413 (Ariz. 1964)). Where a statute contains a severability provision, Arizona courts generally attempt to give effect to the severability clause. Id. at 715. 
Section 12(A) of S.B. 1070 provides for the severability of S.B. 1070's provisions, stating that if any provision of the Act "is held invalid, the invalidity does not affect other provisions ... that can be given effect without the invalid provision.” Arizona's Legislature 
1 A.R.S. § 11-1051(B). Section 2(B) also states that if an officer is presented with one of the

2 following forms of identification, the officer is to presume that the person is not an

3 unauthorized alien: (1) a valid Arizona driver license or identification license; (2) a valid

4 tribal enrollment card or other form of tribal identification; or (3) a valid United States federal,

5 state, or local form of identification, provided that the issuing entity requires proof of

6 citizenship before issuance. Id. The United States argues that this section is preempted

7 because it will result in the harassment of lawfully present aliens and will burden federal

8 resources and impede federal enforcement and policy priorities. (Pl.’s Mot. at 25-32.)

\section{a. Mandatory Immigration Status Determination Upon Arrest} The Court first addresses the second sentence of Section 2(B): "Any person who is arrested shall have the person's immigration status determined before the person is released." Arizona advances that the proper interpretation of this sentence is "that only where a reasonable suspicion exists that a person arrested is an alien and is unlawfully present in the United States must the person's immigration status be determined before the person is released.” (Defs.’ Resp. to Pl.’s Mot. (“Defs.’ Resp.”) at 10.) ${ }^{5}$ Arizona goes on to state, “[T]he Arizona Legislature could not have intended to compel Arizona's law enforcement officers to determine and verify the immigration status of every single person arrested - even for United States citizens and when there is absolutely no reason to believe the person is unlawfully present in the country.” (Id.)

0 The Court cannot interpret this provision as Arizona suggests. Before the passage of H.B. 2162, the first sentence of Section 2(B) of the original S.B. 1070 began, "For any lawful contact" rather than "For any lawful stop, detention or arrest." (Compare original S.B. 1070 § 2(B) with H.B. $2162 \S 3($ B).) The second sentence was identical in the original version and as modified by H.B. 2162. It is not a logical interpretation of the Arizona Legislature's intent to state that it originally intended the first two sentences of Section 2(B) to be read as

${ }^{5}$ Arizona acknowledges that this sentence of Section 2(B) "might well have been more artfully worded.” (Id.) 
1 dependent on one another. As initially written, the first sentence of Section 2(B) did not 2 contain the word "arrest," such that the second sentence could be read as modifying or 3 explicating the first sentence. In S.B. 1070 as originally enacted, the first two sentences of

4 Section 2(B) are clearly independent of one another. Therefore, it does not follow logically 5 that by changing "any lawful contact" to "any lawful stop, detention or arrest" in the first sentence, the Arizona Legislature intended to alter the meaning of the second sentence in any way. If that had been the Legislature's intent, it could easily have modified the second sentence accordingly.

As a result of this conclusion, the Court reads the second sentence of Section 2(B) independently from the first sentence. The Court also concludes that the list of forms of identification that could provide a presumption that a person is not an unlawfully present alien applies only to the first sentence of Section 2(B) because the second sentence makes no mention of unlawful presence: the second sentence states plainly that "[a]ny person who is arrested" must have his or her immigration status determined before release. A presumption against unlawful presence would not dispose of the requirement that immigration status be checked because a legal permanent resident might have a valid Arizona driver's license, but an inquiry would still need to be made to satisfy the requirement that the person's “immigration status" be determined prior to release.

9 The United States asserts that mandatory determination of immigration status for all arrestees "conflicts with federal law because it necessarily imposes substantial burdens on lawful immigrants in a way that frustrates the concern of Congress for nationally-uniform rules governing the treatment of aliens throughout the country - rules designed to ensure 'our traditional policy of not treating aliens as a thing apart."' (Pl.'s Mot. at 26 (quoting Hines $v$. Davidowitz, 312 U.S. 52, 73 (1941)).) Finding a state law related to alien registration to be preempted, the Supreme Court in Hines observed that Congress "manifested a purpose to [regulate immigration] in such a way as to protect the personal liberties of law-abiding aliens through one uniform national ... system[] and to leave them free from the possibility of inquisitorial practices and police surveillance.” 312 U.S. at 74. 
Requiring Arizona law enforcement officials and agencies to determine the immigration status of every person who is arrested burdens lawfully-present aliens because their liberty will be restricted while their status is checked. Given the large number of people who are technically “arrested” but never booked into jail or perhaps even transported to a law enforcement facility, detention time for this category of arrestee will certainly be extended during an immigration status verification. (See Escobar, et al. v. City of Tucson, et al., No. CV fiscal year 2009, Tucson used the cite-and-release procedure provided by A.R.S. § 13-3903 to "arrest" and immediately release 36,821 people).) Under Section 2(B) of S.B. 1070, all arrestees will be required to prove their immigration status to the satisfaction of state authorities, thus increasing the intrusion of police presence into the lives of legally-present aliens (and even United States citizens), who will necessarily be swept up by this requirement. ${ }^{6}$

4 The United States argues that the influx of requests for immigration status determination directed to the federal government or federally-qualified officials would “impermissibly shift the allocation of federal resources away from federal priorities.” (Pl.’s Mot. at 30.) State laws have been found to be preempted where they imposed a burden on a federal agency's resources that impeded the agency's function. See Buckman Co. v. Plaintiffs' Legal Comm., 531 U.S. 341, 351 (2001) (finding a state law preempted in part because it would create an incentive for individuals to "submit a deluge of information that the [federal agency] neither wants nor needs, resulting in additional burdens on the FDA's evaluation of an application”); cf. Garrett v. City of Escondido, 465 F. Supp. 2d 1043, 1057 (S.D. Cal. 2006) (expressing concern in preemption analysis for preliminary injunction purposes that burden on DOJ and DHS as a result of immigration status checks could "impede the functions of those federal agencies”).

${ }^{6}$ The Court is also cognizant of the potentially serious Fourth Amendment problems with the inevitable increase in length of detention while immigration status is determined, as raised by the plaintiffs in Friendly House, et al. v. Whiting, et al., No. CV 10-1061-PHX-SRB. 
Pursuant to 8 U.S.C. § 1373(c), DHS is required to "respond to an inquiry by a Federal, State, or local government agency, seeking to verify or ascertain the citizenship or immigration status ... for any purpose authorized by law, by providing the requested

administered by ICE and "serves as a national enforcement operations center that promptly provides immigration status and identity information to local, state, and federal law enforcement agencies regarding aliens suspected of, arrested for, or convicted of criminal activity.” (Pl.'s Mot. at 6-7 (citing Palmatier Decl. 9ף 3-6).) Mr. Palmatier states in his Declaration that LESC resources are currently dedicated in part to national security objectives such as requests for immigration status determination from the United States Secret Service, the FBI, and employment-related requests at "national security related locations that could be vulnerable to sabotage, attack, or exploitation.” (Palmatier Decl. ๆ 4.) Thus, an increase in the number of requests for determinations of immigration status, such as is likely to result from the mandatory requirement that Arizona law enforcement officials and agencies check the immigration status of any person who is arrested, will divert resources from the federal government's other responsibilities and priorities.

For these reasons, the United States has demonstrated that it is likely to succeed on its claim that the mandatory immigration verification upon arrest requirement contained in Section 2(B) of S.B. 1070 is preempted by federal law. This requirement, as stated above, is likely to burden legally-present aliens, in contravention of the Supreme Court's directive in Hines that aliens not be subject to "the possibility of inquisitorial practices and police surveillance.” 312 U.S. at 74. Further, the number of requests that will emanate from Arizona as a result of determining the status of every arrestee is likely to impermissibly burden federal resources and redirect federal agencies away from the priorities they have established. ${ }^{7}$

${ }^{7}$ The problems associated with burdening federal resources are even more acute when considered in light of other state laws similar to this provision. (See Pl.'s Mot. at 31-32 (citing to a newspaper article stating that at least 18 other states are considering parallel legislation).); see also North Dakota v. United States, 495 U.S. 423, 458-59 (1990) (Brennan, 


\section{b. Immigration Status Determination During Lawful Stops, Detentions, or Arrests}

Next, the Court turns to the first sentence of Section 2(B):

For any lawful stop, detention or arrest made by [an Arizona] law enforcement official or ... law enforcement agency ... in the enforcement of any other law or ordinance of a county, city or town of this state where reasonable suspicion exists that the person is an alien and is unlawfully present in the United States, a reasonable attempt shall be made, when practicable, to determine the immigration status of the person, except if the determination may hinder or obstruct an investigation.

A.R.S. § 11-1051(B). The United States makes essentially the same arguments about this requirement. First, the United States advances that it imposes a burden on lawfully-present aliens not permitted by Hines, where the Supreme Court sought to protect the personal liberties of lawfully-present aliens to leave them free from the possibility of intrusive police practices that might affect international relations and generate disloyalty. (Pl.'s Mot. at 26 (citing Hines, 312 U.S. at 74).) Second, the United States argues that this requirement impermissibly burdens and redirects federal resources away from federally-established priorities. (Id.) The United States' arguments regarding burdening of federal resources are identical to those outlined above and will not be restated. However, the United States makes several arguments with respect to the burden on lawfully-present aliens that are specific to or slightly different in the context of the first sentence of Section 2(B).

First, the United States argues that this provision "necessarily places lawfully present aliens (and even U.S. citizens) in continual jeopardy of having to demonstrate their lawful status to non-federal officials.” (Id. at 26.) The United States further asserts that there are numerous categories of lawfully-present aliens "who will not have readily available documentation to demonstrate that fact," including foreign visitors from Visa Waiver Program

J., concurring in plurality opinion in part and dissenting in part) (collecting cases where burden of state regulation on federal government was amplified by aggregate potential of multiple states following suit). 
countries, ${ }^{8}$ individuals who have applied for asylum but not yet received an adjudication, people with temporary protected status, $\mathrm{U}$ and $\mathrm{T}$ non-immigrant visa applicants, or people who have self-petitioned for relief under the Violence Against Women Act. (Id. at 26-27.) Also, the United States points out that United States citizens are not required to carry identification, and some citizens might not have easy access to a form of identification that would satisfy the requirement of Section 2(B). ${ }^{9}$

The United States contends that the impact on lawfully-present aliens of the requirement that law enforcement officials, where practicable, check the immigration status of a person lawfully stopped, detained, or arrested where there is reasonable suspicion that the person is an alien and is unlawfully present will be exacerbated by several factors. (Id. at 2829.) First, the United States suggests that the impact on lawfully-present aliens is enhanced because this requirement applies to stops for even very minor, non-criminal violations of state law, including jaywalking, failing to have a dog on a leash, or riding a bicycle on the sidewalk. (Id. at 28.) Also, the United States argues that the impact will be increased because other provisions in S.B. 1070 put pressure on law enforcement agencies and officials to enforce the immigration laws vigorously. ${ }^{10}$ (Id. at 29.)

17 Hines cautions against imposing burdens on lawfully-present aliens such as those described above. See 312 U.S. at 73-74. Legal residents will certainly be swept up by this requirement, particularly when the impacts of the provisions pressuring law enforcement

${ }^{8}$ The Visa Waiver Program permits visitors from certain countries to enter the United States without a visa, so long as various requirements are met. See, e.g., 8 U.S.C. § 1187; 8 C.F.R. $\S \S 217.1-217.7$.

${ }^{9}$ Also, upon a check with LESC or a federally-authorized state official, the status of a United States citizen might not be easily confirmable as many people born in the United States likely do not have an entry in a DHS database.

${ }^{10}$ These provisions include Sections $2(\mathrm{~A})$ and 2(H), which, respectively, prohibit agencies from restricting the enforcement of immigration laws and create a private right of action for legal residents to sue agencies if they believe the laws are not being enforced aggressively enough. 
1 agencies to enforce immigration laws are considered. See A.R.S. § 11-1051(A), (H). Certain

2 categories of people with transitional status and foreign visitors from countries that are part

3 of the Visa Waiver Program will not have readily available documentation of their

4 authorization to remain in the United States, thus potentially subjecting them to arrest or

${ }^{11}$ The Court notes, but does not analyze here, the arguments raised by the plaintiffs in Friendly House, No. CV 10-1061-PHX-SRB, regarding racial profiling.

${ }^{12}$ Many law enforcement officials already have the discretion to verify immigration status if they have reasonable suspicion, in the absence of S.B. 1070; Section 2 of S.B. 1070 removes that discretion by making immigration status determinations mandatory where practicable. (See Pl.’s Mot. at 26; Defs.’ Resp. at 20.) 
to an inference of preemption. Therefore, for the purposes of preliminary injunction analysis, the Court concludes that the United States has demonstrated a likelihood of success on its challenge to the first sentence of Section 2(B). Section 2(B) in its entirety is likely preempted by federal law.

\section{Section 3: A.R.S. § 13-1509}

Section 3 states that "a person is guilty of willful failure to complete or carry an alien registration document if the person is in violation of 8 [U.S.C. §§] 1304(e) or 1306(a).” A.R.S. $\S 13-1509$ (A) ${ }^{13}$ The penalties for violation of Section 3, a class 1 misdemeanor, are a maximum fine of $\$ 100$ and a maximum of 20 days in jail for a first violation and up to 30 days in jail for any subsequent violation. A.R.S. § 13-1509(H). Section 3 also limits violators’ eligibility for suspension of sentence, probation, pardon, and commutation of a sentence and requires violators to pay jail costs. A.R.S. § 13-1509(D), (E). Section 3 does not apply to "a person who maintains authorization from the federal government to remain in the United States.” A.R.S. § 13-1509(F). Essentially, Section 3 makes it a state crime to violate federal registration laws and provides for state prosecutions and penalties for violations of the federal registration law. The United States argues that Section 3 is preempted because it interferes with comprehensive federal alien registration law, seeks to criminalize unlawful presence, and will result in the harassment of aliens. (Pl.'s Mot. at 34-39.) Arizona asserts that Section 3 neither conflicts with federal law nor regulates in a federally occupied field. (Defs.' Resp. at 21-22.)

"[T]he power to restrict, limit, regulate, and register aliens as a distinct group is not an equal and continuously existing concurrent power of state and nation[;] . . whatever power

138 U.S.C. $\S 1306($ a) makes it a misdemeanor, subject to a maximum fine of $\$ 1000$ and a maximum of six months imprisonment, to willfully fail or refuse to apply for registration when such application is required. Similarly, 8 U.S.C. § 1304(e) requires an alien to carry a certificate of alien registration or alien registration receipt and makes a failure to comply with these requirements a misdemeanor subject to a maximum fine of $\$ 100$ and imprisonment for up to 30 days. 
1 a state may have is subordinate to supreme national law.” Hines, 312 U.S. at 68. In Hines, the

2 Supreme Court found that,

where the federal government, in the exercise of its superior authority in this field, has enacted a complete scheme of regulation and has therein provided a standard for the registration of aliens, states cannot, inconsistently with the purpose of Congress, conflict or interfere with, curtail or complement, the

312 U.S. at 66-67. Hines also stated that a state statute is preempted where it "stands as an obstacle to the accomplishment and execution of the full purposes and objectives of Congress.” Id. at 67. The Supreme Court determined in Hines that the purpose of the Federal Alien Registration Act was to "make a harmonious whole" and that the Alien Registration Act "provided a standard for alien registration in a single integrated and all-embracing system." Id. at 72,74 . As a result, the Hines court held that the state registration scheme at issue could not be enforced. Id. at 74 .

The current federal alien registration requirements create an integrated and comprehensive system of registration. See id. (finding that the Alien Registration Act, the precursor to the current alien registration scheme, created a "single integrated and allembracing system” of registration); 8 U.S.C. $\S \S 1201,1301-06$ (providing federal registration requirements and penalties). While the Supreme Court rejected the possibility that the INA is so comprehensive that it leaves no room for state action that impacts aliens, De Canas, 424 U.S. at 358, the Supreme Court has also evaluated the impact of the comprehensive federal alien registration scheme and determined that the complete scheme of registration precludes states from conflicting with or complementing the federal law. Hines, 312 U.S. at 66-67. scheme by making it a state crime to violate the federal alien registration requirements, which a state may not do "inconsistently with the purpose of Congress." Hines, 312 U.S. at 66-67; see also A.R.S. § 13-1509(A). While Section 3 does not create additional registration requirements, the statute does aim to create state penalties and lead to state prosecutions for violation of the federal law. Although the alien registration requirements remain uniform, Section 3 alters the penalties established by Congress under the federal registration scheme. 
1 Section 3 stands as an obstacle to the uniform, federal registration scheme and is therefore an

2 impermissible attempt by Arizona to regulate alien registration. See Hines, 312 U.S. at 67. As

3 a result, the Court finds that the United States is likely to succeed on its claim that Section 3

4 is preempted by federal law. ${ }^{14}$

\section{Section 4: Amendment to A.R.S. § 13-2319}

Section 4 of S.B. 1070 amends Arizona’s human smuggling statute, A.R.S. § 13-2319. Section 4 adds, "Notwithstanding any other law, in the enforcement of this section a peace officer may lawfully stop any person who is operating a motor vehicle if the officer has reasonable suspicion to believe the person is in violation of any civil traffic law.” A.R.S. § 132319(E). The United States requests an injunction prohibiting the enforcement of Section 4 but does not seek an injunction as to A.R.S. § 13-2319. (Pl.’s Compl. at 24 (requesting a preliminary and permanent injunction prohibiting the enforcement of Sections 1-6 of S.B. 1070). ${ }^{15}$ However, the arguments asserted by the United States in support of enjoining Section 4 pertain entirely to separate provisions of A.R.S. § 13-2319 and do not challenge the change embodied in Section 4. (Pl.'s Mot. at 39-42.)

Section 4 makes a minor change to Arizona's preexisting human smuggling statute, which is not specifically challenged by the United States. Nothing about the section standing alone warrants an injunction. As a result, the Court finds that the United States is not likely to succeed on a claim that Section 4 of S.B. 1070 is preempted by federal law.

5. Section 5: A.R.S. § 13-2928(C) $)^{16}$

${ }^{14}$ Subsections (B)-(H) pertain to the implementation and enforcement of Section 3. No provisions of Section 3 retain any effect absent Section 3's operative provision.

${ }^{15}$ At the July 22, 2010, Hearing on the United States' Motion for a Preliminary Injunction, the United States confirmed that it does not seek to enjoin A.R.S. § 13-2319. (Hr'g Tr. 5:1020.)

${ }^{16}$ Two provisions of Section 5 prohibit the act of hiring and being hired by the occupant of a motor vehicle. A.R.S. § 13-2928(A), (B). The Court finds that the June 9, 2010, decision of the Ninth Circuit Court of Appeals in a case contesting a virtually identical local ordinance in Redondo Beach, California forecloses a challenge to A.R.S. §§ 13-2928 (A) and (B) on 
Section 5 of S.B. 1070 creates A.R.S. § 13-2928(C), which provides that "it is unlawful for a person who is unlawfully present in the United States and who is an unauthorized alien to knowingly apply for work, solicit work in a public place or perform work as an employee or independent contractor in this state.” This violation is a class 1 misdemeanor. A.R.S. § 132928(F). The United States asserts that this provision "is preempted by Congress's comprehensive scheme, set forth in [IRCA] for regulating the employment of aliens.” (Pl.'s Mot. at 42.) The United States argues that “IRCA reflects Congress's deliberate choice not to criminally penalize unlawfully present aliens for performing work, much less for attempting to perform it.” (Id.) Arizona responds that "Congress could have, but chose not to, expressly preempt state and local laws that impose civil or criminal sanctions upon employees." (Defs.' Resp. at 25.) Arizona contends that, in an area of traditional state sovereignty such as employment, “[p]reemption cannot be lightly inferred.” (Id.)

"States possess broad authority under their police powers to regulate the employment relationship to protect workers within the State.” De Canas, 424 U.S. at 356. Interpreting De Canas and considering a state law sanctioning employers who hire unauthorized workers, the Ninth Circuit Court of Appeals held that, "because the power to regulate the employment of unauthorized aliens remains within the states' historic police powers, an assumption of nonpreemption appli[ed].” Chicanos Por La Causa I, 544 F.3d at 984; accord Wyeth v. Levine, 129 S. Ct. 1187, 1194-95 (2009) (observing that “[i]n all pre-emption cases, and particularly in those in which Congress has legislated . . . in a field which the States have traditionally occupied, ... we start with the assumption that the historic police powers of the States were not to be superseded by the Federal Act unless that was the clear and manifest purpose of Congress" (internal quotations and citation omitted)).

4 A.R.S. § 13-2928(C), as amended, regulates the employment of unauthorized aliens in Arizona, and, thus, a presumption against preemption applies in the context of this

First Amendment grounds. See Comite de Jornaleros de Redondo Beach v. City of Redondo Beach, 607 F.3d 1178, 1184-93 (9th Cir. 2010). 
provision. However, while deliberate federal inaction does not always imply preemption,

2 “[w]here a comprehensive federal scheme intentionally leaves a portion of the regulated field

3 without controls, then the pre-emptive inference can be drawn, not from federal inaction alone but from inaction joined with action." P.R. Dep't of Consumer Affairs v. Isla Petroleum Corp.,

${ }^{17}$ IIRIRA created three pilot programs for employee verification; of those three, only the program commonly known as E-Verify is still in existence. See Chamber of Commerce of the United States v. Edmondson, 594 F.3d 742, 752 (10th Cir. 2010). 
1 fining, detaining or adopting criminal sanctions against the employee, it ultimately rejected 2 all such proposals.” Nat'l Ctr. for Immigrants’ Rights, Inc. v. INS, 913 F.2d 1350, 1368 (9th

3 Cir. 1990) (examining IRCA's legislative history), rev'd on other grounds, 502 U.S. 183

4 (1991). The court in National Center for Immigrants' Rights found that the determination to reduce or deter employment of unauthorized workers by sanctioning employers, rather than employees, was “a congressional policy choice clearly elaborated in IRCA.” Id. at 1370.

IRCA also requires that an individual seeking employment "attest, under penalty of perjury ... that the individual is a citizen or national of the United States, an alien lawfully admitted for permanent residence, or an alien who is authorized . . . to be hired, recruited, or referred for such employment.” 8 U.S.C. § 1324a(b)(2). This attestation is to be made on a form “designated or established by the Attorney General," and IRCA states that the form "and any information contained in or appended to such form[] may not be used for purposes other than for enforcement of this chapter and sections 1001, 1028, 1546, and 1621 of Title 18” of the federal criminal code. Id. $\S 1324$ a(b)(5). The provisions of Title 18 referenced in $\S$ 1324a(b)(5) of Title 8 make it a federal crime to, in any matter within the jurisdiction of the federal government:

(1) falsify, conceal, or cover up any material fact; (2) knowingly make or use a materially false, fictitious, or fraudulent statement; or (3) make or use any false writing or document.

18 U.S.C. § 1028(a): $\quad$ knowingly make, use, or transfer a false or stolen identification document or identification document belonging to another person or any implement or feature for use in creating a false identification document.

18 U.S.C. § 1546:

(a) forge or falsify an immigration document; or (b) use a false identification document, a document not properly issued to the user, or a false attestation.

commit perjury by knowingly making a false statement after taking an oath to tell the truth during a proceeding or on any document signed under penalty of perjury. 
1 Accordingly, the attestation forms described in 8 U.S.C. § 1324a(b)(2) may only be used for

2 these limited purposes.

${ }^{18}$ The United States also asserts in a footnote that A.R.S. § 13-2929 directly conflicts with 8 U.S.C. § 1324(a)(1)(C), a section of the federal alien smuggling statute, which provides an exception for certain religious groups for contact with volunteer ministers and missionaries. (Id. at $46 \mathrm{n}$.40.) While the federal statute includes a narrow exception for religious organizations engaged in certain conduct not specifically exempted under A.R.S. § 13-2929, the new Arizona statute is narrower than its federal counterpart because it requires that the 


\section{a. Regulation of Immigration}

The "[p]ower to regulate immigration is unquestionably exclusively a federal power." De Canas, 424 U.S. at 354. The regulation of immigration is "essentially a determination of who should or should not be admitted into the country, and the conditions under which a legal entrant may remain.” Id. at 355. "[T] he fact that aliens are the subject of a state statute does not render it a regulation of immigration." Id. The United States argues that "to the extent Section 5 is not a restriction on interstate movement, it is necessarily a restriction on unlawful entry into the United States.” (Pl.’s Mot. at 45.)

A.R.S. § 13-2929 does not attempt to regulate who should or should not be admitted into the United States, and it does not regulate the conditions under which legal entrants may remain in the United States. See De Canas, 424 U.S. at 355. Therefore, the Court concludes that the United States is not likely to succeed on its claim that A.R.S. § 13-2929 is an impermissible regulation of immigration.

\section{b. The Dormant Commerce Clause}

The Commerce Clause provides Congress with the power to "regulate Commerce . . . among the several States.” U.S. Const. art. I, § 8, cl. 1, 3. The Supreme Court has interpreted the Commerce Clause "to have a 'negative' aspect that denies the States the power unjustifiably to discriminate against or burden the interstate flow of articles of commerce." Or. Waste Sys., Inc. v. Dep’t of Envtl. Quality, 511 U.S. 93, 98 (1994). This doctrine is often referred to as the “dormant Commerce Clause.” United Haulers Ass'n v. Oneida-Herkimer

person already be in violation of a criminal offense. In light of the intentional narrowing of the Arizona enactment, the Court would have to imagine a set of remote circumstances in order to find a potential conflict between the federal and the state law. In addition, Arizona asserts that A.R.S. § 13-2929 targets criminals who engage unlawfully present aliens to be involved in a criminal enterprise. On a facial challenge, "the challenger must establish that no set of circumstances exists under which the Act would be valid." Salerno, 481 U.S. at 745. In deciding a facial challenge, courts "must be careful not to go beyond the statute's facial requirements and speculate about 'hypothetical' or 'imaginary' cases.” Wash. State Grange, 552 U.S. at 449-50 (quoting Raines, 362 U.S. at 22). A.R.S. § 13-2929 is narrower than the federal law, and the Court will not speculate about hypothetical cases in order to find a conflict between the two. 
1 Solid Waste Mgmt. Auth., 550 U.S. 330, 338 (2007). “The dormant Commerce Clause is

2 implicated if state laws regulate an activity that 'has a substantial effect' on interstate

3 commerce such that Congress could regulate the activity.'” Nat'l Ass'n of Optometrists \&

4 Opticians Lenscrafters, Inc. v. Brown, 567 F.3d 521, 525 (9th Cir. 2009) (quoting

5 Conservation Force, Inc. v. Manning, 301 F.3d 985, 993 (9th Cir. 2002)).

${ }^{19}$ The United States argues that the dormant Commerce Clause "forbids certain state regulations attempting to discourage or otherwise restrict the movement of people between states.” (Pl.'s Mot. at 45 (citing Edwards v. California, 314 U.S. 160, 172-73 (1941)).) However, the United States fails to cite any authority supporting the proposition that unlawfully present aliens must be permitted to travel from state to state. In Edwards, the Supreme Court struck down a California statute prohibiting the transportation of indigent people into California. Edwards, 314 U.S. at 173. Unlike the California statute at issue in Edwards, A.R.S. § 13-2929 prohibits the transportation of people who are unlawfully present in the United States. Moreover, A.R.S. § 13-2929 does not attempt to prohibit entry into Arizona, but rather criminalizes specific conduct already prohibited by federal law. 
Even assuming that A.R.S. § 13-2929 implicates the Commerce Clause, the statutory provision does not discriminate between in-state and out-of-state economic interests. See

\section{7. $\quad$ Section 6: Amendment to A.R.S. § 13-3883(A)}

In Section 6 of S.B. 1070, the Arizona Legislature revised A.R.S. § 13-3883 to provide that an officer may arrest a person without a warrant if the officer has probable cause to believe that "the person to be arrested has committed any public offense that makes the person removable from the United States.” A.R.S. § 13-3883(A)(5). In Arizona, a "public offense” is

conduct for which a sentence to a term of imprisonment or of a fine is provided by any law of the state in which it occurred or by any law, regulation or ordinance of a political subdivision of that state and, if the act occurred in a state other than this state, it would be so punishable under the laws, regulations or ordinances of this state or of a political subdivision of this state if the act had occurred in this state.

A.R.S. § 13-105(26). Because A.R.S. § 13-3883 already provides for the warrantless arrest of a person who commits a felony, misdemeanor, petty offense, or one of certain criminal

${ }^{20}$ The United States asserts that Section 10 of S.B. 1070 "is preempted insofar as it is based on the state law violations identified in Sections 4 and 5, which are preempted for the reasons discussed herein.” (Pl.'s Mot. at 12 n.8.) As discussed above, the Court finds that Sections 4 and 5 are not likely to be preempted by federal law. Therefore, the United States is also not likely to succeed on its claim that Section 10 is preempted. 
violations in connection with a traffic accident, the effect of Section 6 on warrantless arrest authority is not entirely clear. Indeed, the Arizona officer training materials state that the revision to A.R.S. § 13-3883 “does not appear to change Arizona law.” Implementation of the 2010 Ariz. Immigration Laws - Statutory Provisions for Peace Officers 11 (June 2010), http://agency.azpost.gov/supporting_docs/ArizonaImmigrationStatutesOutline.pdf. Both the United States, in its Motion, and Arizona, at the Hearing, suggested that the revision provides for the warrantless arrest of a person where there is probable cause to believe the person committed a crime in another state that would be considered a crime if it had been committed in Arizona and that would subject the person to removal from the United States. (Pl's Mot. at 32-33; Hr'g Tr. 46-48.) What is clear is that the statutory revision targets only aliens-legal and illegal-because only aliens are removable. See Hughes v. Ashcroft, 255 F.3d 752, 756 (9th Cir. 2001) (citing 8 U.S.C. § 1227).

In its brief, Arizona originally asserted that the new provision in A.R.S. § 13-3883 was "based upon a memorandum the DOJ's Office of Legal Counsel prepared in which it concluded that federal law does not 'preclude[] state police from arresting aliens on the basis of civil deportability.”' (Defs.’ Resp. at 14 (quoting id., Ex. 4, Mem. from Jay S. Bybee, Assistant Att'y Gen., Re: Non-preemption of the authority of state and local law enforcement officials to arrest aliens for immigration violations, at 13).) Although neither party asserted it at the Hearing, the Arizona Legislature's intent may have been to provide for the warrantless arrest of an alien who was previously convicted of a crime in Arizona but never referred to DHS for potential removal proceedings. This alternate interpretation of the revision to A.R.S. § 13-3883 would be in keeping with a goal of conferring on state officers the authority to arrest aliens on the basis of civil deportability.

4 Under the interpretation suggested by both parties that the revision to A.R.S. § 13-3883 is directed at the arrest of aliens who committed a crime in another state, the statute first requires an officer to determine whether an alien's out-of-state crime would have been a crime if it had been committed in Arizona, a determination that requires knowledge of out-of-state statutes and their relationship with Arizona's statutes. See State v. Roque, 141 P.3d 368, 391 
1

2

(Ariz. 2006) (concluding that the California and Arizona robbery statutes are not coterminous and, under certain facts, a person may be convicted of attempted robbery in California but not Arizona). Under any interpretation of the revision to A.R.S. § 13-3883, it requires an officer to determine whether an alien's public offense makes the alien removable from the United States, a task of considerable complexity that falls under the exclusive authority of the federal government. Justice Alito has commented that

providing advice on whether a conviction for a particular offense will make an alien removable is often quite complex. "Most crimes affecting immigration status are not specifically mentioned by the [Immigration and Nationality Act (INA)], but instead fall under a broad category of crimes such as crimes involving moral turpitude or aggravated felonies.” M. Garcia \& L. Eig, CRS Report for Congress, Immigration Consequences of Criminal Activity (Sept. 20, 2006) (summary) (emphasis in original). As has been widely acknowledged, determining whether a particular crime is an "aggravated felony" or a "crime involving moral turpitude [(CIMT)]" is not an easy task.

Padilla v. Kentucky, 130 S. Ct. 1473, 1488 (2010) (Alito, J., concurring) (some citations omitted). Within the complicated scheme of determining removability, some federal officials are, under certain circumstances, authorized to change the immigration consequences of the commission of a public offense and cancel or suspend the removal of an alien. See, e.g., 8 U.S.C. $\S \S 1229 b(a), 1253(a)(3)$. Ultimately, immigration court judges and federal appeals court judges determine whether an alien's offense makes an alien removable. See id. $\S$ 1182(a)(2) (describing crimes that qualify as grounds for inadmissibility); id. § 1227(a)(2) (describing crimes that qualify as grounds for deportation).

20 In its Motion, the United States provided evidence that Arizona police officers have no familiarity with assessing whether a public offense would make an alien removable from the United States. (Pl.’s Mot., Ex. 8, Decl. of Tony Estrada, Sheriff of Santa Cruz Cnty. qף 8-9; Ex. 9, Decl. of Roberto Villaseñor, Chief of Police, Tucson Police Dep’t 9 6.) In its Response, Arizona asserted that, under the new A.R.S. § 11-1051, Arizona officers can contact DHS to determine the immigration status of aliens. (Defs.' Resp. at 19.) But the revision to A.R.S. § 13-3883 does not state that an officer must contact DHS to assess 
removability; the revision simply extends the authority for an officer to make a warrantless

2 arrest. $^{21}$ offense makes an alien removable from the United States and the fact that this determination is ultimately made by federal judges, there is a substantial likelihood that officers will wrongfully arrest legal resident aliens under the new A.R.S. § 13-3883(A)(5). By enforcing this statute, Arizona would impose a "distinct, unusual and extraordinary" burden on legal at 65-66. The Court thus finds that the United States is likely to succeed on the merits in showing that A.R.S. $\S 13-3883(A)(5)$, created by Section 6 of S.B. 1070, is preempted by federal law.

\section{Likelihood of Irreparable Harm}

The Supreme Court has repeatedly recognized the "basic doctrine of equity jurisprudence that courts of equity should not act ... when the moving party has an adequate remedy at law and will not suffer irreparable injury if denied equitable relief." Younger $v$. Harris, 401 U.S. 37, 43-44 (1971). Thus the United States also has the burden to establish that, absent a preliminary injunction, there is a likelihood-not just a possibility-that it will suffer irreparable harm. Winter, 129 S. Ct. at 374-75.

9 The Ninth Circuit Court of Appeals has stated "'that an alleged constitutional infringement will often alone constitute irreparable harm."” Monterey Mech. Co. v. Wilson, 125 F.3d 702, 715 (9th Cir. 1997) (quoting Assoc. Gen. Contractors of Cal., Inc. v. Coal. for

${ }^{21}$ Even if an officer does contact LESC for the immigration status of an alien, it is not clear that LESC will have any information regarding whether a particular public offense that an alien may have committed will make the alien removable from the United States. "Congress established the LESC to provide alien status determination support to federal, state, and local law enforcement on a 24-hour-a-day, seven-days-a-week basis. The enabling legislation is codified in 8 U.S.C. $\S \S 1226(d)(1)(A) \& 1252$ Note.” (Palmatier Decl. ๆ 5.) The statute only directs LESC to determine the immigration status of an arrested individual. 8 U.S.C. $\S$ 1226(d)(1)(A). For its part, Arizona did not provide any evidence that LESC would be able to advise an officer whether a particular public offense makes an alien removable. 
1 Econ. Equal., 950 F.2d 1401, 1412 (9th Cir. 1991)). Indeed, if an individual or entity faces

2 the imminent threat of enforcement of a preempted state law and the resulting injury may not

3 be remedied by monetary damages, the individual or entity is likely to suffer irreparable harm.

4 See Morales v. Trans World Airlines, Inc., 504 U.S. 374, 381 (1992) (stating that a federal

5 court may properly enjoin "state officers 'who threaten and are about to commence

6 proceedings, either of a civil or criminal nature, to enforce against parties affected an

7 unconstitutional act, violating the Federal Constitution"” (quoting Ex parte Young, 209 U.S.

8 123, 156 (1908)); New Orleans Pub. Serv., Inc. v. Council of New Orleans, 491 U.S. 350,

9 366-67 (1989) (suggesting that irreparable injury is an inherent result of the enforcement of

10 a state law that is preempted on its face); Edmondson, 594 F.3d at 771 (concluding that

11 plaintiff is likely to suffer irreparable injury if enforcement of state law that is likely

12 preempted by IRCA and IIRIRA is not enjoined); Villas at Parkside Partners v. City of

13 Farmers Branch, 577 F. Supp. 2d 858, 878 (N.D. Tex. 2008) (concluding that there is a

14 likelihood of irreparable injury if enforcement of a city ordinance that is preempted by the

15 INA is not enjoined).

16 If enforcement of the portions of S.B. 1070 for which the Court finds a likelihood of 17 preemption is not enjoined, the United States is likely to suffer irreparable harm. This is so 18 because the federal government's ability to enforce its policies and achieve its objectives will 19 be undermined by the state's enforcement of statutes that interfere with federal law, even if 20 the Court were to conclude that the state statutes have substantially the same goals as federal 21 law. See Crosby v. Nat'l Foreign Trade Council, 530 U.S. 363, 379-80 \& n.14 (2000). For

22 this injury, the United States will have no remedy at law. The Court thus finds a likelihood 23 of irreparable harm to the interests of the United States that warrants preliminary injunctive 24 relief. See Am. Ins. Ass'n v. Garamendi, 539 U.S. 396, 413, 427 (2003) (enjoining 25 permanently the enforcement of a state statute that is preempted by federal law because it 26 interferes with the federal government's ability to enforce its policies); Crosby, 530 U.S. at 27 372, 379-80 (same). 


\section{The Balance of Equities and the Public Interest}

The United States also has the burden to show that the balance of equities tips in its favor and that a preliminary injunction is in the public interest. Winter, 129 S. Ct. at 374. "A preliminary injunction is an extraordinary remedy never awarded as of right.” Id. at 376 (citing Munaf v. Green, 128 S. Ct. 2207, 2218-19 (2008)). “In each case, courts ‘must balance the competing claims of injury and must consider the effect on each party of the granting or withholding of the requested relief,"” paying particular attention to the public consequences. Id. at 376-77 (quoting Amoco Prod. Co. v. Vill. of Gambell, Alaska, 480 U.S. 531, 542 (1987)).

The Ninth Circuit Court of Appeals has concluded that allowing a state to enforce a state law in violation of the Supremacy Clause is neither equitable nor in the public interest. Cal. Pharmacists Ass'n v. Maxwell-Jolly, 563 F.3d 847, 852-53 (9th Cir. 2009); Am. Trucking Ass'ns, Inc. v. City of L.A., 559 F.3d 1046, 1059-60 (9th Cir. 2009). If Arizona were to enforce the portions of S.B. 1070 for which the Court has found a likelihood of preemption, such enforcement would likely burden legal resident aliens and interfere with federal policy. A preliminary injunction would allow the federal government to continue to pursue federal priorities, which is inherently in the public interest, until a final judgment is reached in this case. See Am. Trucking, 559 F.3d at 1059-60.

The Court by no means disregards Arizona's interests in controlling illegal immigration and addressing the concurrent problems with crime including the trafficking of humans, drugs, guns, and money. Even though Arizona's interests may be consistent with those of the federal government, it is not in the public interest for Arizona to enforce preempted laws. See Edmondson, 594 F.3d at 771. The Court therefore finds that preserving the status quo through a preliminary injunction is less harmful than allowing state laws that are likely preempted by federal law to be enforced. See Cal. Pharmacists, 563 F.3d at 852-53; Am. Trucking, 559 F.3d at 1059-60.

IT IS THEREFORE ORDERED granting in part and denying in part the United States' Motion for Preliminary Injunction (Doc. 27). 
IT IS FURTHER ORDERED denying the United States' Motion for Preliminary

\section{2} Section 1, Section 2(A) and (C)-(L), Section 4, the portion of Section 5 creating A.R.S. § 132929, the portion of Section 5 creating A.R.S. § 13-2928(A) and (B), and Sections 7-13.

Governor Brewer from enforcing the following Sections of Senate Bill 1070 (as amended by House Bill 2162): Section 2(B) creating A.R.S. § 11-1051(B), Section 3 creating A.R.S. $\S$

DATED this 28th day of July, 2010. 